\title{
Tracing the Diffusion of Internet in Malaysia: Then and Now
}

\author{
Ali Salman ${ }^{1}$, Er Ah Choy ${ }^{2}$, Wan Amizah Wan Mahmud ${ }^{1} \&$ Roslina Abdul Latif $^{1}$ \\ ${ }^{1}$ School of Media and Communication Studies, Faculty of Social Sciences and Humanities, Universiti \\ Kebangsaan Malaysia, Malaysia \\ ${ }^{2}$ School of Social, Development and Environmental Studies, Faculty of Social Sciences and Humanities, \\ Universiti Kebangsaan Malaysia, Malaysia \\ Correspondence: Ali Salman, School of Media and Communication Studies, Faculty of Social Sciences and \\ Humanities, Universiti Kebangsaan Malaysia, Malaysia. Tel: 60-19-612-6568. E-mail: asalmanphd@gmail.com; \\ asalman@ukm.my
}

Received: March 14, 2013 Accepted: April 19, 2013 Online Published: April 28, 2013

doi:10.5539/ass.v9n6p9 URL: http://dx.doi.org/10.5539/ass.v9n6p9

\begin{abstract}
The Internet has brought about a huge change in the way we do things and on many aspects of our society. The advent of the Internet in Malaysia dates back to 1995, which was considered the beginning of the Internet age in Malaysia. The aim of this paper is to trace the diffusion of Internet in Malaysia until present. The growth in the number of Internet hosts in Malaysia began around 1996. The country's first search engine and web portal company was also founded that year. From the first Malaysian Internet survey conducted from October to November 1995 by MIMOS and Beta Interactive Services, one out of every thousand Malaysians had access to the Internet then (20,000 Internet users out of a population of 20 million). The National Public Policy Workshop (NPPW) in 2005 proposed tremendous changes towards a strategy to move forward the uptake of ICT and internet in Malaysia. Among the outcomes of the NPPW is the High Speed Broadband initiative which was launched in 2010. As of July 2012 internet users in Malaysia reached 25.3 million. Out of that number, there are 5 million broadband users, 2.5 million wireless broadband users and 10 million $3 \mathrm{G}$ subscribers. With access to the Internet been largely achieved, the next step would be to maximise the use of the Internet in achieving digital inclusion and gaining cultural capital.
\end{abstract}

Keywords: internet diffusion, internet in Malaysia, High Speed Broadband (HSBB), Multimedia Super Corridor (MSC), digital inclusion

\section{Introduction}

The Internet has brought about a huge change in the way we do things and on many aspects of our society. It triggers innovation in a different manner from previous technologies, with new ideas spreading quickly across national borders (Xue, 2005). Malaysia is no exception to this development. Like in many other countries, the Internet has now become ubiquitous in the life of Malaysians. It is a household name, especially with the advent of Facebook. Malaysia has seen a meteoric rise in Internet usage among its populations couple with high broadband penetration.

In comparison with other developing countries, the Malaysian government had earlier begun formulating a national strategy for telecommunications, including the Internet. There are several important documents and strategies determining the information and Internet policy. One of them is Malaysia's Vision 2020 launched in 1991 by Dr Mahathir, the then Prime Minister. It stipulated where the country wanted to go in the future and why, and outlined the goal for Malaysia to become a developed nation come 2020.

In the mid-1990s, the government deepened its obligation to ICT. Hence, in 1994, a team of consultants was appointed to determine steps and strategies to achieve the goal of Vision 2020. An advisory group, National Information Technology Council (NITC), was established and launched the National IT Agenda (NITA) in 1996. NITA provides a framework for use of ICT in Malaysia, viewing ICT development from three perspectives: people, infrastructure and applications (Hashim \& Yusof, 1999).

Malaysia's Internet initiative and development began in 1990 with the establishment of Malaysian Institute of Microelectronic Systems (MIMOS) and the subsequent launching of Joint Advanced Integrated Networking (JARING) as the main Internet Service Provider. In 1992 a satellite was installed to link Malaysia and the USA 
and JARING was fully connected to the Internet, henceforth providing Malaysian users with access to Internet resources in more than 140 countries (Hashim \& Yusof, 1999).

However, the year 1995 was considered the beginning of the Internet age in Malaysia. The growth in the number of Internet hosts in Malaysia began around 1996, when the government seriously engaged in ICT development and opened the telecommunication market to three additional companies. The country's first search engine and web portal company was also founded that year (Pillai, 2001).

The aim of this paper is to trace the diffusion of Internet in Malaysia till now and to suggest the way forward in further improving the use of the Internet to expedite digital inclusion. Access to internet among the natives and migrants is also presented. In addition, literacy/knowledge of internet application and gratification derived from using the internet among the migrants and natives are also discussed. The challenges facing Internet adoption and usage will also be highlighted. Basically this paper is based on secondary data derived from literature review. However, a primary data from a survey research conducted in the second quarter of 2011 on 600 respondents, who are grouped into natives and migrants, residing in the Klang Valley is used to enrich the paper. In addition to percentages, means and standard deviation are used to analyse the data.

\section{Tracing the Diffusion of Internet in Malaysia}

Following the ICT initiatives, the growth in the number of Internet hosts in Malaysia began around 1996. The first search engine and web portal company, Cari Internet, was also founded that year. From the first Malaysian Internet survey conducted from October to November 1995 by MIMOS and Beta Interactive Services, only one out of every thousand Malaysians had access to the Internet then (20,000 Internet users out of a population of 20 million) (Pillai, 2001). This number grew to $2.6 \%$ of the population in 1998. The total number of computer units sold, which was 467,000 in 1998 and 701,000 in 2000 indicated an increasing growth (Lee, 2000c).

In 1996, the Multimedia Super Corridor (MSC), the main vehicle for achieving Vision 2020, was officially launched. The objective of MSC is to build a world-leading technology environment to facilitate Malaysia's progression into a knowledge-based society, by attracting and fostering leading-edge and world-class companies (Multimedia Super Corridor, 2003).

Information and Communication Technology (ICT) is now the spotlight to lead Malaysia in the new epoch of globalization and knowledge. The government has put in place the Multimedia Super Corridor (MSC) covering an area of 15 kilometres wide and 50 kilometres long covering Kuala Lumpur City Center (KLCC) in the north and the new KL International Airport (KLIA) in the south (Ariff \& Goh, 1998, p. 9; Samsudin, 1998, p. 83). Located within the Corridor are two cities known as Putrajaya and Cyberjaya. Putrajaya, the new headquarters of the Malaysian Government, is known as an "intelligent city" because it has all the latest facilities for the Information Age, and it uses information technology to help modernize the system of government and administration, (known as "electronic government"). Cyberjaya is the base for some of the world's largest and most innovative multimedia companies, which are expected to set up their industrialized or creative centres, use the most refined multimedia technology to manufacture their products and provide services for the global market. It is also planned to house universities, smart homes, smart schools and several research and development (R\&D) centres (Ariff \& Goh, 1998, p. 10). The smart concept as used by Malaysian government means the use of ICT in daily routine.

In 1998, the Communications and Multimedia Act was passed to accomplish the need to standardize an increasingly convergent communications and multimedia industry. The Act is based on these basic principles: transparency and clarity; more competition and less regulation; flexibility; bias towards generic rules; regulatory forbearance; emphasis on process rather than content; administrative and sector transparency; and industry self-regulation (MCMC, 1998).

The National Information Technology Council of Malaysia (NITC MALAYSIA) is the country's premier organization that manages ICT in the interest of the nation. The Council functions as the primary advisor and consultant to the Government on matters pertaining to ICT in Malaysia's national development. The Council officially organize annually. Membership for the council is for a period of two years and is by appointment of the Honorable Prime Minister. Council members come from three different sectors i.e. public, private and community interest group. The Council have smart partnerships or strategic association to carry out its mandate (NITC Malaysia, 2012).

The Prime Minister's Office and the National Information Technology Council (NITC) are also important advisors and players in formulating national information policy and strategy. An advisory group, NITC, was 
established and launched the National IT Agenda (NITA) in 1996. NITA provides a framework for use of ICT in Malaysia, viewing ICT development from three angles: people, infrastructure and applications (Xue, S.2005)

The Malaysian government in the late 1990s launched the "One Home, One Computer" policy where Malaysians having savings with the Employee Provident Fund (EPF) were allowed to withdraw some of their EPF saving for the purpose of buying a computer to encourage Malaysian families to buy domestic PCs by making it possible to borrow money (up to 4000 Ringit) against their retirement funds. Several households I visited had taken advantage of this offer (Bell, 2006).

Another important development and turning point on policy in the application of Internet in Malaysia is The National Public Policy Workshop (NPPW) which was conducted in 2005. The NPPW notes that programs need to be put in place to increase workplace competency by first analyzing workforce requirements. End-user training has to be provided on a regular basis and there should be increased support towards the SMEs ICT players. Questions were raised on the issue of Internet Provider (IP) ownership of government applications. The group on R\&D raised the issue regarding the significance of learning the success and failure from $R \& D$ funded by the government to ensure mistakes are not repeated. The group suggested that a knowledge-sharing outlet must be developed to ensure the sharing of this information between the government and other stakeholders in order to drive the cycle of innovation (NPPW, 2005).

\section{The Current Scenario of Internet Diffusion in Malaysia}

Malaysia has come a long way as far as development in Internet usage is concern. The country is experiencing a giant leap in her efforts to remain resilient as far as the National IT and Communications strategy is concerned. This is demonstrated by Malaysia's 11th place ranking in 2008 in the Brookings Institution's assessment of e-government readiness among 198 nations in their governance studies. Malaysia's ranking was 25th place in 2007. This is an improvement in score from 36.9 to 42.8. Malaysia is thus amongst the most highly ranked e-government nations, a result of the public sector ICT initiatives (West, 2008). This effort was nurtured during the era of Tun Dr. Mahathir Mohamad, the then-Prime Minister of Malaysia (Hamzah \& Hamzah, 2001) and Malaysians in general are responding to this effort. Malaysia has 25.3 million Internet users as of July 2012 (Datuk Fadillah Yusof, 2012).

Malaysia has made big strides as far as the adoption and use of the internet is concerned. This is obvious in the various governmental ICT initiatives such as the National Public Policy Workshop (NPPW) in 2005 which proposed tremendous changes towards strategy to move forward the uptake of ICT and internet in Malaysia (Salman, 2010). There are also the Multimedia Super Corridor (MSC) and the newly launched High Speed Broadband (HSBB) (Salman, 2010; The Malay Mail, March 2010).

The HSBB is a flagship project of the National Broadband Initiative and aims to boost the country's competitiveness. The national project, worth RM11.3bil (US\$1.00 = RM3.1), is a joint effort between Telekom Malaysia (TM), a Malaysian Telecommunication Company, and the government to develop the next generation high speed broadband infrastructure and services. Some of the initiatives include implementation of broadband community centres to provide services to 615,000 households in 246 locations with an allocation of RM60 million.

Other initiatives also comprise the building of people's internet centres in 138 Information Ministry premises nationwide providing broadband coverage to 400,000 users. E-kiosks will also be provided at community centres and sub-district offices in 1,105 sub-districts in the country with an allocation of RM40. There is a provision for public cellular coverage whereby 873 new telecommunication towers will be built, as well as 278 telecommunication towers in Sabah and 257 in Sarawak; channelling of RM1 billion from the Universal Service Provision (USP) programme through the agreement of service providers to provide notebooks to underprivileged students in the country; and a TM agreement to introduce broadband-netbook packages at reduced prices of RM38 (from RM50) and RM20 (from RM30) for USP areas.

High Speed Broadband (HSBB) was to be implemented in certain areas to encourage business and economic growth and Broadband to the General Population (BBGP) shall be installed. The NBI fragment the nation into three zones. Zone 1 comprises of high economic impact areas such as the Klang Valley and Iskandar Development Region in Johor. Zone 2 includes towns and subarban areas. Whilst Zone 3 primarily includes rural areas.

In Zone 1 Telekom Malaysia will offer high-speed broadband (HSBB) access of up to to $10 \mathrm{Mbps}$. Residents in the zone will also have access to competitive broadband solutions provided by other service providers. Four 
initial areas to be covered by HSBB TM service include Shah Alam, Subang Jaya, Taman Tun Dr Ismail, and Bangsar.

The NBI plan includes the participation of service providers to offer broadband services in Zone Two. Broadband access in Zone 3 areas will be spearheaded by Malaysian Communications and Multimedia Commission (MCMC) using Universal Service Provision (USP) funds. Broadband access in these areas shall also include Basic Telephony Access (via fixed and mobile networks), broadband connected Community Broadband Libraries (CBLs) and Community Broadband Centres (CBCs). Cellular coverage areas will be expanded through the construction of more communications towers financed by the USP fund. This will enable cellular operators to enlarge their coverage to 97 percent of the population by 2011 .

The HSBB is under the auspices of the National Broadband Initiative (NBI). Included in this initiative is also allocation of one million 1Malaysia Netbooks for allocation to qualified recipients such as secondary and university students as well as other lower-income groups to ensure that they have the opportunity to access the Internet and also to increase broadband usage throughout the country. This is part of the effort to contribute to the nation's broadband penetration rate as well as extend the benefits of broadband to students and the nation. Distribution of the 1Malaysia Netbooks with ready broadband access to the identified target groups is divided into the following ratio:

1) Some 65 percent of the 1Malaysia Netbooks will be distributed among students from low-income families with priority given to secondary students of Government funded or assisted schools and university students who still do not possess broadband subscriptions.

2) Some 35 percent of the 1Malaysia Netbooks to be given out to low-income groups and also to targeted groups living in the underserved areas that have low broadband penetration rate but with complete communication infrastructure and services.

The identification of students from low-income families is made with the assistance of the relevant Ministries and Government agencies. A household income of RM 3,000 and below is used as an indicator of potential recipients within the low-income groups.

So far internet adoption and use in Malaysia has been encouraging with the younger generation at the helm of adoption based on data from a survey on Malaysian Internet users (Table 1) conducted in the middle of 2011 under FRGS research grant. In the table, the natives belong to generation Y who were born in the Internet age, while the migrants refer to the generation who were born long before the Internet.

Table 1. Internet access and use

\begin{tabular}{lrr}
\hline & Natives (N=300) & Migrants (N=300) \\
\hline Internet Subscription & $215(71.7 \%)$ & $222(74 \%)$ \\
Years of Internet Usage: & & \\
Less than 6 mths & $24(8 \%)$ & $29(9.7 \%)$ \\
6 mths to 1 yr & $34(11.3 \%)$ & $52(17.3 \%)$ \\
2 to 3 yrs & $72(24 \%)$ & $92(30.7 \%)$ \\
4 to 5 yrs & $56(18.7 \%)$ & $33(11 \%)$ \\
More than 5 yrs & $114(38 \%)$ & $94(31.3 \%)$ \\
Hours of Internet Usage: & & \\
Never use & $32(10.7 \%)$ & $67(22.3 \%)$ \\
Less than 3 hrs per week & $72(24 \%)$ & $83(27.7 \%)$ \\
4 to 7 hrs per week & $51(17 \%)$ & $48(16 \%)$ \\
8 to 11 hrs per week & $46(15.3 \%)$ & $30(10 \%)$ \\
12 to 14 hrs per week & $99(33 \%)$ & $72(24 \%)$ \\
\hline
\end{tabular}

\section{Challenges in the Diffusion of Internet}

Behind this ICT development in Malaysia is the Bill of Guarantee which has been seen as responsible for 
encouraging usage of the internet. The Bill of Guarantee No. 7 states that the government will not censor the internet. However, this does not mean that any person may disseminate illegal content with impunity and without regard to the law (Rahim \& Pawanteh, 2011). Actions can be taken against contents that are deemed seditious, defamatory or contravene the Official Secrets Act 1972. Malaysia as a multi-ethnic and multi-religious society is very sensitive to anything that may jeopardise the peace and harmony of the country (Salman, 2011).

Despite the developments in the diffusion of Internet, there are challenges and Malaysia is not spared from such challenges. Common among these challenges are cyber attacks and hackings, which are worrying. Like any other country, Malaysia also bears the brunt of the new media by way of cyber attacks when the authorities were pushing for stringent piracy laws.

In the middle of 2011 Malaysia had to step up monitoring of government websites to stop a threatened hacking attack by Internet vigilante group Anonymous over government acts of censorship. The hacker group said it would target the Malaysian government's online portal to teach the country a lesson for censoring whistle-blower site WikiLeaks in an attack codenamed "Operation Malaysia." Malaysia was the latest in a cyber-war waged by the activists, who gained prominence when they temporarily crippled the websites of MasterCard and Paypal (Reuters, 2011).

During the attacks at least some 41 Malaysian government websites were hacked into overnight, though, no personal or financial data were compromised. In the attacks, 51 websites were hit and at least 41 of these sites were disrupted (Communications and Multimedia Commission, 2011). Top of the hacked list was www.malaysia.gov.my. The attacks were launched one day ahead of their threat to carry out the cyber onslaught. The other sites hacked into belonged to the Information Ministry (www.kpkk.gov.my), the Fire and Emergency Services Department (www.bomba.gov.my), the Land Public Transport Commission (www.spad.gov.my), and Parliament (www.parlimen.gov.my). Other related agencies sites which were down included Sabah Tourism (www.sabahtourism.com) and Construction Industry Development Board (www.cidb.gov.my). It also included Asean Connect, Treasury, Jobs Malaysia, and National Sports Council among others. All the sites, except CIDB, are completely inaccessible. These sites were allegedly experiencing DDoS (Distributed Denial-of-Service) attacks or switched off by website administrator.

\section{The Way Forward in the Diffusion of Internet}

With access to the Internet been largely achieved in Malaysia, the next step would be to maximise the use of the Internet in achieving digital inclusion and gaining cultural capital. To achieve the above, ICT literacy is crucial while at the same time maximising the gratification obtained from using the Internet.

Data on young Internet users, known as natives showed they spent more hours socializing on the net with friends and family. For this group of people to continue using the Internet, efforts must be made to provide more facilities for social networking that can empower them to participate in discussions concerning public issues.

The Internet is increasingly becoming a place to buy and sell things. Hence for an all inclusive digital inclusion, the use of Internet for online transactions such as shopping/e-business/paying bills must be encouraged. As it is now, the literacy level for online shopping is very low and the use of this application is very minimal among Malaysians (Table 2).

Table 2. Literacy/knowledge of various internet applications

\begin{tabular}{lcccc}
\hline & \multicolumn{2}{c}{ Natives } & \multicolumn{2}{c}{ Migrants } \\
& Mean & SD & Mean & SD \\
\hline Email & 3.86 & .927 & 3.55 & 1.086 \\
Social Media (Facebook, Twitter, Myspace, etc. & 3.92 & .909 & 3.57 & 1.043 \\
Blog & 3.19 & 1.115 & 2.94 & 1.199 \\
Search Engine & 3.90 & .934 & 3.64 & 1.061 \\
Online games & 3.14 & 1.111 & 2.81 & 1.185 \\
Downloading and Uploading of Music, Video, etc. & 3.61 & .973 & 3.24 & 1.122 \\
Online banking & 2.99 & 1.210 & 2.91 & 1.241 \\
E-shopping/e-business & 2.66 & 1.201 & 2.72 & 1.236 \\
\hline
\end{tabular}

Note: $\mathrm{SD}=$ Standard Deviations 
To increase the gratifications derived from using the Internet, technology motivation and literacy knowledge of the Internet, need to be further improved (Table 3). From the findings, these variables have high impact on gratifications and improving them will improve the gratifications derive from the internet resulting in digital inclusion among Malaysians. However, online shopping is among the lowest gratification obtained and mechanisms need to be put in place to augment the use of the Internet for this purpose. The very nature of the internet technology should be attractive and appealing to the young generation, while what is crucial for the older generation is the provision of ICT literacy and knowledge to speed up digital inclusion.

Table 3. Gratification from using internet

\begin{tabular}{lcccc}
\hline & \multicolumn{2}{c}{ Natives } & \multicolumn{2}{c}{ Migrants } \\
& Mean & SD & Mean & SD \\
\hline Quick on current issues & 4.22 & .828 & 4.12 & .836 \\
Quick on information & 4.30 & .799 & 4.18 & .769 \\
Easy making Friends & 4.09 & .923 & 4.02 & .795 \\
Realtime interaction with friends & 3.97 & .826 & 3.95 & .840 \\
People get to know me through blog & 3.60 & 1.054 & 3.49 & 1.068 \\
Internet shopping makes it easy to choose & 3.21 & 1.153 & 3.22 & 1.177 \\
Easy to get materials/books for reference & 3.52 & 1.096 & 3.44 & 1.094 \\
Social Media makes it easier to give opinion & 3.83 & .928 & 3.65 & 1.050 \\
Confidence in mixing with friends because I get lot of & 3.80 & .922 & 3.66 & .960 \\
$\quad$ information from internet & & & & \\
Internet provides me with information to solve & 4.06 & .896 & 3.83 & .951 \\
$\quad$ problems & & & & \\
Internet help relieves boredom & 4.10 & .879 & 3.81 & 1.014 \\
Happy playing online games & 3.40 & 1.213 & 3.08 & 1.243 \\
Can make online transaction/ pay bills & 3.51 & 1.158 & 3.48 & 1.152 \\
\hline
\end{tabular}

Note: $\mathrm{SD}=$ Standard Deviations

\section{Conclusion}

Malaysia has made a lot of gains as far as the usage of ICT and internet is concerned. The public sector with the support of the private sector have played important role in the diffusion of the Internet. As the primary data has shown, the gap is closing between the native and migrant users of internet.

Despite all the initiatives and investments in new technologies, especially the Internet and its applications, continuous efforts still need to be made in bringing about digital inclusion, which is at the moment lacking. Having access to the Internet does not guarantee inclusion. Digital inclusion will only come about when the Internet provides gratification and added value to the users. This in turn will help in gaining cultural capital which is vital for the development of any society.

This paper concurs with Wilhelm (2004) who is with the view that investing in new technologies is no recipe for success because by having the tools alone, which is the case in most wealthy nations, does not guarantee performance. More needs to be done by way of literacy campaign on what Internet can offer in terms of added value. Anything short of this will only mean doing same things in different ways. Rather new technologies are supposed to add value and bring about efficiency and empowerment.

\section{References}

Ariff, I., \& Goh, C. C. (1998). Multimedia Super Corridor. Kuala Lumpur: Leeds.

Bell, G. (2006). Satu Keluarga, Satu Komputer (One Home, One Computer): Cultural Accounts of ICTs in South and Southeast Asia. Design Issues, 22(2). http://dx.doi.org/10.1162/desi.2006.22.2.35

Clarke, D. (2003). Developing Capacities for ICT Enabled Development. Capacity.org, (18), 20-25. 
Hamzah, M., \& Hamzah, M. (2001). Information Communication Technology in Malaysia: A passage to the future. In R. Hashim, \& G. Becker (Eds.), Internet Malaysia. Bangi (Malaysia): Department of Communication, UKM.

Hashim, R., \& Becker, G. (Eds.). (2001). Internet Malaysia. Bangi (Malaysia): Department of Communication, UKM.

Hashim, R., \& Yusof, A. (1999). Internet in Malaysia. Retrieved January 10, 2012, from http://www.interasia.org/malaysia/hashim-yusof.html

MCMC. (n. d.). MCMC Law and Legislation. Retrieved November 13, 2011, from

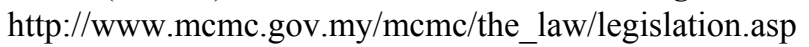

Multimedia Super Corridor. (2003). About MSC - the Multimedia Super Corridor. Retrieved November 13, 2011, from http://www.msc.com.my/msc/msc.asp

National Public Policy Workshop. (2005). Kuala Lumpur; The Government of Malaysia (A workshop organized by the Malaysian Government).

NITC Malaysia. (2012). NITC Malaysia. Retrieved January 12, 2012, from http://www.nitc.my/index.cfm?\&menuid=15

Pillai, S. (2001). Malaysia's oldest search engine upbeat in trying times. CNETAsia. Retrieved January 1, 2012 , from http:/www.zdnetasia.com/msia-oldest-search-engine-upbeat-in-trying-times-39001129.htm

Reuters. (2011a). Hackers disrupt 41 Malaysian government websites. Retrieved January 1, 2012, from http://in.reuters.com/article/2011/06/16/idINIndia-57724420110616

Reuters. (2011b). Malaysia tries to stop threatened cyber attack. Retrieved January 1, 2012, from http://www.reuters.com/article/2011/06/15/us-cyber-malaysia-idUSTRE75E05N20110615

Salman, A. (2010). ICT, the New Media (Internet) and Development: Malaysian Experience. The Innovation Journal: The Public Sector Innovation Journal, 15(1).

Samsudin A. R. (1998). Mass Media and National Development: The Malaysian Experience. In M. S. Hasim, S. A. Rahim, \& B. Tukhtabayev (Eds.), Mass Media and National Development: Experiences of Malaysia and Uzbekistan (pp. 75-90). Kuala Lumpur: International Center for Media Studies.

West, D. M. (2008). Improving Technology Utilization in Electronic Government around the World. Brookings $\begin{array}{lllll}\text { Institution. } & \text { Retrieved } & \text { January } & \text { from }\end{array}$ http://www.brookings.edu/ /media/Files/rc/reports/2008/0817_egovernment_west/0817_egovernment_west .pdf

Wilheim, A. G. (2004). Digital Nation: Toward an Inclusive Information Society. Massachusetts: MIT Press.

Xue, S. (2005). Internet policy and diffusion in China, Malaysia and Singapore. Journal of Information Science, 31(238). http://dx.doi.org/10.1177/0165551505052472

Yatim, R. (2011). World Bloggers \& Social Media Summit 2011. Retrieved November 20, 2011, from http:/www.malaysianwireless.com/2011/06/malaysia-broadband-3g-users/

Yusof, D. F. (2012). Internet use, online safety must go together. Retrieved February 5, 2013, from http:/www.theborneopost.com/2012/07/07/internet-use-online-safety-must-go-together-fadillah/\#ixzz2JzUj iie 7 